January 2015

\title{
Regulating Information Flows in Capital Markets
}

Onnig $\mathrm{H}$. Dombalagian

Tulane University of Louisiana

\section{Recommended Citation}

Onnig H. Dombalagian, Regulating Information Flows in Capital Markets, 68 SMU L. REV. 727 (2015) https://scholar.smu.edu/smulr/vol68/iss3/14 


\title{
Regulating INFORMATION Flows in Capital Markets
}

\author{
Onnig H. Dombalagian*
}

\begin{abstract}
$O$
INCE the New Deal, U.S. securities law has been grounded in the twin goals of "full and fair disclosure" and "fair and honest markets." 1 To this end, the Securities and Exchange Commission (SEC) and other U.S. securities regulators historically have focused on compelling ever-increasing disclosures from issuers and capital markets intermediaries to facilitate publicly informed trading. As adaptive tools emerge to facilitate the aggregation and transformation of information for financial decision-making, ${ }^{2}$ it has become equally important to consider not just what is disclosed, but how information is processed and used throughout the information production chain-from originators, through intermediaries, and ultimately, by end users.

In recent years, the SEC and other market regulators accordingly have come to pay greater attention to the entire process by which information is gathered, verified, disseminated, and used. ${ }^{3}$ In particular, the informational infrastructure of securities markets traditionally has relied on a subset of highly regulated entities to intermediate information flows on behalf of the public - these include issuers, exchanges, investment banks, auditors, lawyers, securities analysts, and credit rating agencies. Information tends to flow through these well-regulated nodes in securities markets, often to the exclusion of new channels or categories of intermediation. In the wake of the near collapse of our financial sector over the past decade, policy makers have not only sought to assess the relative culpability of these intermediaries, but have also questioned their faith in the continued vitality of the regulatory framework we inherited from the twentieth century.

As we reflect on the life and scholarship of Professor Bromberg, one of our nation's preeminent scholars in securities regulation, it is an opportune time to look forward as well and to sketch the informational arrangements and regulatory infrastructure necessary to meet the needs of the twenty-first century. As information flows upend established intermediaries and transcend national markets, policy makers must

* George Denégre Professor of Law, Tulane University School of Law

1. Securities Act of 1933, Pub. L No. 73-22, 48 Stat. 74, 74; 15 USC $\$ 78 b$ (2012).

2. See, e.g., Tom C.W. Lin, The New Investor, 60 UCLA L. Rev. 678, 703-10 (2013).

3. See Onnig H. Dombalagian, Chasing the Tape: Information Law and PolICY IN CAPITAL MARKETS 1-3 (2015). The ideas introduced in this contribution are more fully developed in my monograph.
\end{abstract}


decouple the principles that govern information creation, compilation, processing, verification, and dissemination from increasingly arbitrary statutory classifications and jurisdictional boundaries. Instead, they must move toward a holistic regulation of the information production chain. This contribution considers the objectives of information regulation in capital markets, contemporary challenges to the current regulatory framework, and some perspectives on the future of capital markets regulation.

\section{REVISITING THE OBJECTIVES OF INFORMATION REGULATION}

The goals of capital markets regulation are often couched in lofty terms such as "investor confidence" and "investor protection," which defy precise definition. ${ }^{4}$ When speaking about the regulation of information flows in securities markets, scholars often invoke the concept of market efficiency-how quickly and costlessly new information is incorporated into market prices - as the touchstone for framing the goals of regulatory policy. ${ }^{5}$ Gilson and Kraakman's seminal "mechanisms of market efficiency," for example, explain that the cost of acquiring, processing, and verifying information dictates how information is distributed among market participants. ${ }^{6}$ As a result, the relative efficiency of a market will turn upon the extent to which regulatory and commercial intermediaries reduce the collective cost of compiling, processing, and disseminating information so that market prices can efficiently move toward equilibrium. ${ }^{7}$

The use of, or reliance on, intermediaries is not itself costless, of course: intermediaries may fail to exercise due diligence, succumb to conflicts of interest, or fall prey to the same irrational behavior as nonprofessional investors. ${ }^{8}$ Even as technological advances reduce acquisition, processing, and verification costs, financial innovation heightens the need for informational intermediaries to understand new products and vouch for their suitability. ${ }^{9}$ The regulation of financial information thus presents many of the same policy ends and means as other forms of commercial information that are imbued with an element of consumer protection or public interest.

To address these challenges, policy makers must remain open to new approaches to achieving these longstanding objectives of information policy in capital markets. Chief among these regulative objectives is promot-

4. See Donald C. Langevoort, The SEC as a Lawmaker: Choices About Investor Protection in the Face of Uncertainty, 84 WASH. U. L. REv. 1591, 1599-1612 (2006).

5. Ronald J. Gilson \& Reinier H. Kraakman, The Mechanics of Market Efficiency, 70 VA. L. REv. 549, 554-59 (1984).

6. Id. at 565 .

7. Id. at 612-13.

8. See, e.g., Steven L. Schwarcz, Rethinking the Disclosure Paradigm in a World of Complexity, 2004 U. Ill. L. Rev. 1, 11-17 (2004); Charles R.P. Pouncy, Contemporary Financial Innovation: Orthodoxy and Alternatives, 51 SMU L. REv. 505, $576-89$ (1998).

9. See, e.g., Henry T. C. Hu, Too Complex to Depict? Innovation, "Pure Information," and the SEC Disclosure Paradigm, 90 TEx. L. REv. 1601, 1671-75 (2012). 
ing transparency, fair access, standardization, verification, and interpretative transformation, while policing information flows for integrity and reliability, with a view to economizing on the costs of information dissemination and use. In each case, traditional approaches have relied on direct regulation of information originators or the intermediation of highly regulated entities in the information production chain. More modern approaches, meanwhile, tend to carve out room for private ordering and market-based mechanisms.

\section{A. Calibrating Transparency and Access}

Most of capital markets regulation naturally focuses on calibrating the disclosure and dissemination of information-be it in the form of company disclosures published by issuers of financial instruments, market data from exchanges and other trading venues, or data and indices used in more elaborate financial contracts or products. Those who own or control the flow of information often have incentives to restrict its availability or accessibility. For example, supporters of mandatory disclosure and transparency rules often argue that an exclusive creator or provider of information may refuse to release it or compile it in a form suitable for use by others, whether because of the cost of production, the impact of public disclosure on its other operations, the incentive to discriminate among potential users, or the ability to control downstream uses. ${ }^{10}$

Securities laws, therefore, mandate some degree of transparency or access on the grounds that information is a public good or that disclosure is necessary to prevent fraudulent, opportunistic, or unfairly discriminatory behavior. Disclosure and data dissemination requirements may be imposed on public companies based on factors such as size and profitability or the diffusion and sophistication of their shareholder base. ${ }^{11}$ Regulators might also seek to dictate the price and contractual terms on which market information is licensed or accessed, or alternatively, to regulate complex licensing arrangements that finance the cost of producing or verifying information. ${ }^{12}$

At the same time, there is a growing recognition that transparency and access rules need to be better tailored to the needs of individual issuers and investors and to the objectives of particular trading markets. As a result, novel approaches to tiering transparency and access requirements often incorporate market-based elements. For example, academics have renewed efforts to conceive of more elaborate systems to provide order-

10. See, e.g., John C. Coffee, Jr., Market Failure and the Economic Case for a Mandatory Disclosure System, 70 VA. L. Rev. 717, 723-37 (1984); Merritt B. Fox, Retaining Mandatory Securities Disclosure: Why Issuer Choice Is Not Investor Empowerment, 85 VA. L. REV. 1335, 1343-46 (1999).

11. See, e.g., Donald C. Langevoort \& Robert B. Thompson, "Publicness" in Contemporary Securities Regulation After the JOBS Act, 101 GEo. L.J. 337, 351-71 (2013); Jeff Schwartz, The Law and Economics of Scaled Equity Market Regulation, 39 J. CorP. L. 347, 352-56 (2014).

12. See Dombalagian, supra note 3, at 107-13. 
ing for issuers and investors beyond the decision to go public or list on an exchange. ${ }^{13}$ Meanwhile, policy makers have taken concrete steps to develop market-based systems for tiering information disclosure to facilitate transactions among issuers and investors-particularly for the benefit of smaller companies for whom traditional mandatory disclosure requirements are prohibitively expensive. ${ }^{14}$

\section{B. Deregulating Standardization}

Regulators also routinely grapple with the problem of structuring information to make it amenable to comparative analysis. Standardization of narrative disclosures, financial statements, market prices, or asset-level data facilitates comparison of similar products or transactions. Technical standards, for example, are necessary for the accessibility and interoperability of market systems. At the same time, standards for the content and format of information can become unnecessary (and unhelpful) when information users are able to exercise their own judgment as to how to compare information, ${ }^{15}$ or when they threaten to dampen heterogeneity in the interpretation of information. ${ }^{16}$

The way standards are promulgated often is as important as the content of standards because of the dynamic standard-setting process. Policy makers, for example, must decide whether to "make or buy" standards for compliance with disclosure or access requirements. ${ }^{17}$ Traditionally, regulators have preferred to set standards themselves or to delegate standardsetting to highly regulated standard-setting bodies, such as exchanges or self-regulatory organizations. Such approaches may nevertheless frustrate innovation in the development and dissemination of information, particularly to the extent that standard-setters are not responsive to changes in the marketplace.

More recently, regulators have shown a greater willingness to tolerate the co-existence of standards and to delegate more authority to standardsetting organizations, such as with respect to U.S. and international ac-

13. See, e.g., Roberta Romano, The Advantage of Competitive Federalism fOR SeCurities Regulation 112-46 (2002); Stephen Choi, Regulating Investors Not Issuers: A Market-Based Proposal, 88 CAL. L. Rev. 279, 310-26 (2000); Alan R. Palmiter, Toward Disclosure Choice in Securities Offerings, 1999 Colum. Bus. L. Rev. 1, 108-20.

14. See 15 U.S.C. \& 77d(b) (2012) (exempting platforms for trading in certain privately placed securities from broker-dealer regulation); Directive 2014/65, of the European Parliament and of the Council of 15 May 2014 on Markets in Financial Instruments and Amending Directive 2002/92/EC and Directive 2011/61/EU, recit. 132 \& art. 33, 2014 O.J. (L 173) 349, 368, 418-19 (encouraging development of trading facilities for "small and medium-sized enterprises"); see also Jose Miguel Mendoza, Securities Regulation in LowTier Listing Venues: The Rise of the Alternative Investment Market, 13 FORDHAM J. CORP. \& FIN. L. 257, 273-83 (2008).

15. See Mark A. Lemley \& David McGowan, Legal Implications of Network Economic Effects, 86 CAL. L. REv. 479, 491-98 (1998).

16. See infra note 23.

17. See, e.g., Sidney A. Shapiro, Outsourcing Government Regulation, 53 Duke L.J. $389,390-95$ (2003). 
counting standards or internal controls for financial reporting. ${ }^{18}$ As delegation becomes the norm, policy makers must assure themselves of the representativeness, objectivity, and flexibility of the processes used by standard-setters in establishing, interpreting, and modifying standards, as well as the public's ability to access privately developed standards. ${ }^{19}$ In some cases, this may entail establishing governance and funding arrangements designed to eliminate undue influence of major market participants and to promote responsiveness. to emerging conditions. ${ }^{20}$

\section{Improving the Quality and Utility of Information}

Professional intermediaries map meaning onto data to create higher orders of information and knowledge. Informational intermediariessuch as investment banks, exchanges, and benchmark providers-perform a variety of services to help investors and traders process, verify and interpret information in capital markets. Some intermediaries (such as data vendors) merely aggregate information from a variety of sources, whereas others (such as auditors and underwriters) verify the quality the information provided by an information originator. Still others may transform information gathered from multiple sources into an opinion, index, rating, or other more actionable format. Reliance on the efforts of such intermediaries may significantly reduce the cost of diligence and decisionmaking by investors and traders.

The use of intermediaries nevertheless raises questions about how to monitor their diligence and conflicts of interest. Regulators have taken a variety of approaches to regulating the role of informational intermediaries in capital markets, particularly in the wake of recent crises. In some cases, information providers have been (and remain) regulated as an industry utility-regulators grant such providers significant privileges vis-à-vis other market participants and subject them to more intensive supervision to ensure the quality of their product. ${ }^{21}$ More commonly, the reflexive response to financial crises has been to impose (or, once imposed, to heighten) professional or fiduciary obligations on producers and third-party gatekeepers, such as underwriters, accountants, lawyers, analysts, and credit-rating agencies. ${ }^{22}$

For other types of information, financial incentives and performance standards may strengthen commercial pressure to maintain quality and integrity. For example, regulating interpretive intermediation-such as

18. See, e.g., Securities Act Release No. 8879, 73 Fed. Reg. 986 (Jan. 4, 2008); Securities Act Release No. 8238, 68 Fed. Reg. 36636, 36642 (June 18, 2003) (recognizing standards for internal controls over financial reporting under federal securities disclosure).

19. Administrative Conference of the United States, Recommendation 2011-5, Incorporation by Reference at 2 (Dec. 8,2011 ) (stating that "the greatest challenge agencies face" when incorporating private standards by reference or otherwise encouraging their use is to ensure that interested parties have reasonable access).

20. See Dombalagian, supra note 3 , at 126-30.

21. See, e.g., Ruben Lee, Running the World's Markets 126-44 (2011).

22. John C. Coffee, JR., Gatekeepers: The Professions and Corporate Gov. ERNANCE 333-56 (2006). 
discovering prices or opining as to credit risk-through mandatory rules or professional responsibilities may result in an undesirable homogeneity of trading methods or rating methodologies. ${ }^{23}$ By contrast, more modern regulatory approaches are geared toward improving responsiveness to public needs. For example, new compensation models may eliminate conflicts of interest and encourage accountability to users of information, ${ }^{24}$ while performance standards based on measurable outcomes may encourage creative diversity. ${ }^{25}$

\section{Promoting Real-Time Integrity}

Regulators also play an important role in ensuring the integrity of financial information and the infrastructure of capital markets. ${ }^{26}$ Investors and intermediaries generally expect information to be available and accessible in a fair and orderly manner, free of distortion or manipulation. Fraudulent or manipulative activity can take a variety of forms, including trading activity designed to artificially affect market prices, or submission of orders designed to disrupt the trading activity of others. ${ }^{27}$ The theft or abuse of inside information and other market-moving information is increasingly regarded as a threat to confidence in public markets. ${ }^{28}$ The glitches that plagued the Facebook IPO and triggered the Flash Crash of May 6, 2010, have likewise focused attention on the reliability of the operational systems that process information flows. ${ }^{29}$

23. See, e.g., Staff of the Securities and Exchange Commission, Credit Rating STANDaRdization Study 21 (Sept. 2012).

24. Stephen J. Choi \& Jill E. Fisch, How to Fix Wall Street: $A$ Voucher Financing Proposal for Securities Intermediaries, 113 Y ALE L.J. 269, 314-28 (2003); Jeffrey Manns, Rating Risk After the Subprime Mortgage Crisis: A User Fee Approach for Rating Agency Accountability, 87 N.C. L. REv. 1011, 1059-69 (2009).

25. See, e.g., Cary Coglianese et al., Performance-Based Regulation: Prospects and Limitations in Health, Safety, and Environmental Protection, 55 Admin. L. Rev. 705, 714-19 (2003) (discussing the utility of performance-based standards in regulation). But see Roberta S. Karmel, Should a Duty to the Corporation Be Imposed on Institutional Shareholders?, 60 Bus. LAw. 1, 18-21 (2004) (questioning whether performance statistics for institutional investors encourage short-term focus); Lynn Bai, The Performance Disclosures of Credit Rating Agencies: Are They Effective Reputational Sanctions?, 7 N.Y.U. J. L. \& Bus. 47, 59-71 (2010) (critiquing pre-Dodd-Frank rules that resulted in "substantially inconsistent" reported data).

26. See, e.g., International Organization of Securities Commissions, Regula. tory IsSues Raised by the Impact of Technological Changes on Market IntegRITY AND EFFICIENCY 8 (consultation report, CR02-11, July 2011).

27. See, e.g., 1 Philip McBride Johnson \& Thomas Lee Hazen, Derivatives Regulation, \$5.02[1]-[2] (2003); Rosa M. Abrantes-Metz et al., Revolution in Manipulation Law: The New CFTC Rules and the Urgent Need for Economic and Empirical Analyses, 15 U. PA. J. Bus. L. 357, 362-69 (2013).

28. Regulation 596/2014, art. 8, 2014 O.J. (L 173) (Market Abuse Regulation); see also John C. Coffee, Jr., Introduction: Mapping the Future of Insider Trading Law: Of Boundaries, Gaps, and Strategies, 2013 Colum. Bus. L. Rev. 281, 296-311 (2013).

29. See, e.g., Regulation Systems Compliance \& Integrity, Exchange Act Release No. 73639, 79 Fed. Reg. 72252 (Dec, 5, 2014) (adopting requirements for certain regulated entities "to comply with requirements with respect to the automated systems central to the performance of their regulated activities"). 
Regulators have traditionally relied on private antifraud litigation, in addition to public enforcement actions, to deter manipulative and deceptive conduct in the United States. As scholars have called into question the costs and benefits of private litigation, policy makers have come to rely more heavily on public enforcement and real-time surveillance mechanisms to address market integrity concerns. ${ }^{30}$ While stock exchanges and other self-regulatory organizations generally have carried the burden of establishing and maintaining such systems, the increasing fragmentation of trading markets and competition among exchanges has compelled policy makers to devise alternative information gathering and monitoring mechanisms. ${ }^{31}$

These more intrusive forms of regulation may require greater and more frequent disclosure of proprietary or customer information by market participants. In particular, as part of Congress's efforts to regulate systemic risk, the federal financial regulators have amassed the authority to define and collect a broad array of information about the positions and transactions of legal entities throughout the marketplace. ${ }^{32}$ These developments implicate the rights of market intermediaries and their customers to preserve the confidentiality of their trading and investment strategies. ${ }^{33}$

\section{CHALLENGES TO INFORMATION POLICY}

Advances in information technology have transformed capital markets in a variety of ways, such as reducing the cost of gathering and disseminating information, and facilitating the real-time aggregation and processing of financial data. These advances, however, have forced regulators, markets, and intermediaries to reconfigure regulatory strategies to oversee the information production chain holistically. For example, automation has severely taxed the infrastructure for information dissemination created by regulators and regulated markets since the 1970s, while information overload threatens to overwhelm the bounded rationality of human investors and traders. Increasing globalization of capital markets has likewise required regulators worldwide to consider how to share or allocate jurisdiction over information products that facilitate cross-border trading and investment.

30. Compare William W. Bratton \& Michael L. Wachter, The Political Economy of Fraud on the Market, 160 U. PA. L. Rev. 69, 70 (2011), with James D. Cox, Securities Class Actions as Public Law, 160 U. PA. L. Rev. PENNumbra 73 (2011).

31. Consolidated Audit Trail, Exchange Act Release No. 67457, 77 Fed. Reg. 45722, 45727-28 (Aug. 1, 2012) (requiring a national market system plan to create, implement, and maintain a consolidated order tracking system).

32. 12 U.S.C. $\$ \S 5343,5344$ (2012).

33. See Annette L. Nazareth \& Margaret E. Tahyar, Transparency and Confidentiality in the Post Financial Crisis World-Where to Strike the Balance?, 1 HARv. Bus. L. Rev. 145, 158-75 (2011). 


\section{A. Automation}

The automation of trading has revolutionized financial markets. Exchanges and rival trading venues have used new order display, routing, and execution technologies to handle a greater volume of orders at lower cost, and with greater speed and certainty of execution. Meanwhile, institutional investors, market makers, and proprietary traders have automated the analysis and execution of trading decisions. As a result, automation is often credited for reducing transaction costs and improving certain measures of liquidity and informational efficiency in securities and derivatives markets. ${ }^{34}$

At the same time, automation often appears to threaten the accessibility and reliability of our market infrastructure. New breeds of high-frequency and algorithmic traders have capitalized on infinitesimal informational advantages and inefficiencies in the trading infrastructure of markets. While popular narratives decry their ability to eke out profits at the expense of retail investors, ${ }^{35}$ their use of high-speed trading also heightens the risk of adverse selection for market makers and the risk of front-running to institutional investors. ${ }^{36}$ Moreover, weaknesses in order display and access systems, and intermarket controls may not only exacerbate opportunities for classic market disruption or manipulation, but also increase the risk of nonlinear reactions to new information and of disruptive feedback loops (as the Flash Crash of 2010 illustrated). ${ }^{37}$

More generally, corporate issuers and interpretive intermediaries must reconfigure disclosure and dissemination practices to adapt to new patterns of information use as human judgment is replaced by algorithms. Efforts to promote interactive disclosure of narrative and financial information may provide investors with better tools for making financial decisions, but will increasingly squeeze out the contributions of less sophisticated institutional and retail investors to short-term price discovery. For example, the periodic or episodic disclosures that lawyers and accountants carefully craft for both retail and institutional consumption are often torn apart by algorithms within milliseconds. ${ }^{38}$

34. Concept Release on Equity Market Structure, Exchange Act Release No. 61358, 75 Fed. Reg. 3594 (Jan. 21, 2010) ("Equity Market Concept Release"); ForesighT: THE Future of Computer Trading in Financial Markets, London: UK Government Office for Science (2012).

35. See, e.g., Michael Lewis, Flash Boys (2014).

36. See, e.g., Larry Harris, Trading and ExChanges 251 (2003) (describing parasitic order anticipation strategies); Equity Market Concept Release, supra note 34, at 3613.

37. Findings Regarding the Market Events of May 6, 2010: Report of the Staffs of the CFTC and SEC to the Joint Advisory Committee on Emerging RegULATORY Issues 76-79 (Sept. 30, 2010).

38. Compare Elizabeth Blankespoor et al., Initial Evidence on the Market Impact of the XBRL Mandate, 20 REv. AcCounting Studies (forthcoming 2015) (finding wider abnormal bid-ask spreads, a reduction in abnormal liquidity, and a decrease in abnormal trading volume, particularly for small trades, in the market immediately following the introduction of XBRL tagging), with Joung W. Kim et al., The Effect of Mandatory XBRL Reporting across the Financial Information Environment: Evidence in the First Waves of Mandated U.S. Filers, 26 J. INFO. SYs. 127 (2012) (finding "an increase in information effi- 
These issues require policy makers to take a fresh look at how they frame the goals of regulation-both at the level of market structure and broader capital markets policy. Traditionally, policy makers have responded to automation by increasing trading controls and surveillance tools, proposing to dampen or regulate certain trading strategies, or redoubling efforts to protect professionally informed trading from free-riding and predatory trading practices. ${ }^{39}$ At a more abstract level, regulators must consider how fairly and efficiently they can administer policies that seek to promote "universally informed" trading as algorithmic trading upends the idea of simultaneous and costless access to information.

One major shift would be to downplay the longstanding (if quixotic) norm of universal access to information flows. As the practical feasibility of providing retail investors with equivalent access to information and trading opportunities wanes, a regime of fair and nondiscriminatory access might improve price discovery by ensuring that all nodes along the information chain enjoy equivalent access to information flows in relation to their willingness to invest in the technology and expertise necessary to exploit them. ${ }^{40}$

More generally, policy makers could view the entire information production chain as one integrated system that should be subject to uniform access rules. These rules might extend not only to traditional originators and intermediaries in capital markets, but to news, government statistics, and other public information affecting prices in securities and commodities markets consistent with constitutional protections for freedom of the press. ${ }^{41}$ Such rules should nevertheless be offset by corresponding protections for retail and less sophisticated institutional investors who cannot keep up with the financial "arm's race." 42

\section{B. INFORMATION ANXIETY}

Scholars have also increasingly sounded concern that the volume of information coursing through today's financial markets overtaxes the cognitive capabilities of information providers and users. The value of information is naturally bounded by the tools available to map meaning onto raw data; higher orders of knowledge and analysis require us to develop increasingly intricate layers of abstraction in order to organize information effectively. Such anxiety can be attributed to a variety of

ciency, a decrease in event return volatility, and a reduction of change in stock returns volatility" in the post-XBRL disclosure of sampled firms).

39. Dombalagian, supra note 3, at 172-76.

40. Stephen J. Choi, Selective Disclosures in the Public Capital Markets, 35 U.C. DAvIS L. REV. 533, 572-73 (2002). For example, high-speed or high-frequency trading strategies that are profitable only because of clandestine arrangements with information providers may run dry if all traders have equal access to them.

41. Donna M. Nagy \& Richard W. Painter, Selective Disclosure by Federal Officials and the Case for an FGD (Fairer Government Disclosure) Regime, 2012 WIs. L. REV. 1285, 1351-65 (2012).

42. See, e.g., Charles Duhigg, A Smarter Computer to Pick Stocks, N.Y. Times, Nov. 24, 2006 (quoting Andrew Lo). 
sources, including the ratcheting of lengthy, complex, or detailed disclosure requirements; the increasingly granular allocation of risk through financially innovative products; the increasing fragmentation of information across multiple sources; and the diminished role of traditional intermediaries in facilitating collective diligence. ${ }^{43}$

In the long run, complexity should spur the emergence of new intermediaries or technologies to help end users standardize, process, and interpret information more effectively; one policy approach, therefore, is to focus solely on the information production cost to originators when scaling disclosure or dissemination regimes. ${ }^{44}$ Others, in contrast, have argued that the information deluge leads to poorer short-term decisionmaking, as heuristics or cognitive biases increasingly overtake rational analysis and disrupt the efficient design, analysis, and pricing of financial instruments. ${ }^{45}$ Traditional policy responses to these concerns include, among other steps, more paternalistic discretion over the products offered in capital markets, ${ }^{46}$ or heightening the fiduciary and professional obligations of informational intermediaries and institutional investors. ${ }^{47}$

At the same time, policy makers must do more than reshuffle responsibility among a handful of regulated entities or information channels. They must also think about creating room for alternative nodes and channels in the information chain of global capital markets. At the level of basic regulatory infrastructure, regulators might take steps to better differentiate the treatment of intermediaries based on the nature of the services they provide. For example, gatekeeping responsibilities may make the most sense for overseeing the activities of intermediaries that verify information, while performance standards and incentive-based compensation may provide a better-tailored regulatory framework for intermediaries that use public information and perform a predominantly interpretive function.

Promoting opportunities for greater competition and collaboration among upstart intermediaries might further fuel interpretive intermediation. A regulatory policy encouraging good-faith use of smaller intermediaries over established intermediaries may improve competition

43. Dombalagian, supra note 3 , at $180-83$.

44. Schwartz, supra note 11 , at 352-56.

45. See, e.g., Troy A. Paredes, Blinded by the Light: Information Overload and Its Consequences for Securities Regulation, 81 W ASH. U. L. Q. 417, 417 (2003); Schwarcz, Rethinking the Disclosure Paradigm, supra note 8, at 1; Hu, Too Complex to Depict?, supra note 9, at 1601; Joan MacLeod Heminway, The SEC's New Line-Item Disclosure Rules for AssetBacked Securities: MOTS or TMI?, 35 Hamline L. Rev. 385, 405-11 (2012).

46. See, e.g., Eric A. Posner \& E. Glen Weyl, An FDA for Financial Innovation: Applying the Insurable Interest Doctrine to Twenty-First-Century Financial Markets, $107 \mathrm{Nw}$. U. L. Rev. 1307, 1348-57 (2013); Saule T. Omarova, License to Deal: Mandatory Approval of Complex Financial Products, 90 Wash. U. L. Rev. 63, 113-29 (2012) (proposing, in addition to "economic purpose," an "institutional capacity" test of the firm's ability to manage risk and a "systemic effects" test); see also Adam J. Levitin \& Susan M. Wachter, Explaining the Housing Bubble, 100 GEO. L.J. 1177, 1256 (2012) (suggesting standardization of derivatives and structured finance product offerings).

47. Schwarcz, supra note 8, at 17-20. 
for analytic services. ${ }^{48}$ Some scholars have likewise advocated an "opensource inspired approach" to level informational asymmetries and collaboratively detect flaws in models used by financial intermediaries. ${ }^{49}$ Regulators might further foster the development of new entrants by pairing fair access with reasonable accommodations to downstream technologies, and overriding contract terms that unreasonably restrict interoperability or the transformation of information in creative ways.

\section{Globalization}

Globalization has forced policy makers to think about how to regulate the flow of information across borders as capital markets have become increasingly interconnected and interdependent. Capital markets have benefited significantly from the surge of cross-border investment, trading, and financial services activity. In response, the world's major securities exchanges have undergone a wave of transnational mergers and mutual investments with a view to creating transnational platforms for offering and trading securities of global interest. ${ }^{50}$ As regulation becomes the binding constraint on further integration of international markets, national regulators must balance the costs and benefits of extending information policy extraterritorially, on the one hand, and relying on market discipline and the diligence of their regulatory counterparts, on the other.

There is much room for diversity in the regulation of information products. ${ }^{51}$ For example, corporate governance and disclosure practices might vary based on the legal, cultural, and economic arrangements in different jurisdictions. The organization and composition of national and regional markets will also call for different regulatory approaches to price discovery and benchmark development. Regulators naturally fear, however, that liberalization of regulatory standards will result in a "race to the bottom" if they are unable to harmonize standards and coordinate supervision across borders. As a result, they have traditionally asserted the right to regulate transactions conducted in or with significant effects in their territorial jurisdiction, ${ }^{52}$ while looking for ways to coordinate information

48. See, e.g., art. 8d of Regulation (EC) $1060 / 2009,2009$ OJ (L 302) 1, as amended by Regulation (EU) 513/2011, 2011 OJ (L 145) 30, and Regulation (EU) 462/2013, 2013 OJ (L 416) 1 (exhortation regarding the use of smaller credit-rating agencies).

49. See Erik F. Gerding, Code, Crash, and Open Source: The Outsourcing of Financial Regulation to Risk Models and the Global Financial Crisis, 84 WASH. L. REV. 127, 186-95 (2009).

50. See Roberta S. Karmel, The Once and Future New York Stock Exchange: The Regulation of Global Exchanges, 1 Brook. J. Corp. FiN. \& Com. L. 355, 356-58 (2007) (describing the impetus for cross-border mergers of financial exchanges and the regulatory challenges faced by the SEC and EU capital markets regulators).

51. See Annelise Riles, Managing Regulatory Arbitrage: A Conflict of Laws Approach, 47 Cornel. InT'L L.J. 63, 106-07 (2014).

52. See, e.g., Richard W. Painter, The Dodd-Frank Extraterritorial Jurisdiction Provision: Was It Effective, Needed or Sufficient?, 1 Harv. Bus. L. Rev. 195, 199-205 (2011) (discussing recent Congressional debate over the extraterritorial application of Rule 10b5). 
sharing with peer regulators in areas of mutual concern. ${ }^{53}$

The regulation of information does not always easily fit into these categories. Channels for the collection of some types of information may entail a sufficient degree of sovereign interest to warrant exclusive home country regulation. For example, the borrowing costs of domestic banks (a component of interest rate benchmarks such as LIBOR) may be shrouded in secrecy during times of market stress, ${ }^{54}$ while the privacy expectations of homeowners whose mortgages underlie an issue of mortgage-backed securities might always remain a matter of domestic consumer finance policy. Likewise, channels for the communication or dissemination of certain investment strategies or product offerings at the retail level ought to reflect domestic norms insofar as they must play a role in financial planning for education, childrearing, and retirement.

As such jurisdictional boundaries blur, regulators have tepidly embraced more flexible approaches to managing information flows while minimizing regulatory arbitrage. Traditional tools include accommodation of foreign practices or global standards in domestic regulation, mutual recognition of foreign regulation, and, in some cases, deference to the parties' choice of regulatory regime..$^{55}$ While these strategies have been explored largely in the context of issuer disclosures, EU regulators have also confronted the difficulties of harmonizing cross-border flows of market information and benchmark regulation in the context of integrating the markets of its member states. The globalization of exchanges and other quasi-public standard-setting bodies has offered an additional opportunity for transnational regulation of capital markets. ${ }^{56}$

To this end, capital markets regulators might consider several steps to eliminating barriers to harmonization. First, they must identify and agree to respect sovereign interests with respect to disclosure requirements or information channels that entail core domestic interests (e.g., inter-bank lending, residential finance). Second, regulators should revisit disclosure and dissemination requirements with a view to reallocating domestic responsibility for matters of national or cultural relevance (e.g., executive compensation, corporate governance, social disclosures) out of capital markets law. ${ }^{57}$ Elements of disclosure and information dissemination that touch upon concerns about the marketing of securities might also be rewritten into business conduct rules for domestic intermediaries, rather than capital markets disclosure standards.

53. See, e.g., IOSCO, Multilateral Memorandum of Understanding Concerning Consultation and Cooperation and the Exchange of Information (rev. May 2012), \$ 6(a) (committing signatories to "mutual assistance and the exchange of information for the purpose of enforcing and securing compliance with the respective Laws and Regulations of the jurisdictions of the Authorities").

54. See, e.g., Stephen M. Bainbridge, Reforming Libor: Wheatley Versus the Alternatives, 9 N.Y.U. J. L. \& Bus. 789, 836-37 (2013).

55. Domballagian, supra note 3, at 202-06.

56. See, e.g., Steven M. Davidoff, Regulating Listings in a Global Market, 86 N.C. L. REV. 89, 145-48 (2007).

57. Langevoort \& Thompson, supra note 11 , at 374-75. 
If domestic channels could thus be compartmentalized, regulators may find it easier to delegate the establishment and maintenance of global information channels to private or quasi-public standard-setting bodies. For example, issuer disclosure requirements might be standardized by competing regulated exchanges or regulated markets that operate a global tier of trading under coordinated regulatory oversight. Meanwhile, to compensate for the lack of effective oversight of foreign entities, regulators might increasingly rely on algorithmic tools to screen for problematic accounting practices, fraudulent disclosures, manipulative trading, or benchmark manipulation.

\section{CONCLUSION}

As technology, financial innovation, and globalization erode the twentieth-century framework for capital markets regulation, policy makers must work to reframe traditional regulatory practices in light of the larger information chain in which they operate. Competition and lowered entry costs have increased the fluidity of the nodes and channels through which information travels in financial markets. While regulators may build and mandate certain channels for information production and dissemination, they must increasingly rely on fair disclosure and fair access principles to exploit more flexible private infrastructures for information flow. The multiplicity of originators and users populating the information production chain will also make coordinating standards within and across borders an increasingly difficult task.

The more nodes in the system, the greater the diffusion of responsibility for diligence, analysis, and value additivity borne by each. The recent financial crisis-together with many of the episodic shocks to financial markets over the past decade-has tested the wisdom of relying on an extended production chain. But the information age compels us to move forward. There may be some temptation-and occasionally some benefit-to relying on trusted intermediaries with established regulatory responsibilities in lieu of the diffuse and untamed network that increasingly informs modern capital markets. However, a regulatory framework grounded in access and interoperability-backstopped by the mandate of transparency and the fear of surveillance, where appropriate-may better prepare us for the innovations that lie ahead. 
